\title{
eHieho - laskuri uudistuseläinten kasvatuksen kustannusten selvittämiseen maitotiloilla
}

Hannu Viitala, Risto Kauppinen, Pirjo Suhonen, Jyri Tuovinen ${ }^{1}$, Marita Jääskeläinen, Tomi Pasanen

Savonia-ammattikorkeakoulu, PL 72, 74101 Iisalmi, risto.kauppinen(at)savonia.fi

\section{TIIVISTELMÄ}

Suomalaisen maidontuotannon kannattavuus ja kilpailukyky edellyttävät kustannustehokuutta. Uudistuskustannus eli hiehonkasvatuksen kustannukset ovat 10-15\% maidon tuotantokustannuksesta. Uudistuskustannus voi olla jopa puolet maidontuotannon muuttuvista kustannuksista. Hiehon kasvatusajalla on merkitystä eläimen elinikäistuotokseen eli siihen, kuinka paljon se tuottaa maitoa elämänsä aikana. Kiinnittämällä huomio hiehon ruokintaan ja hoitoon, saadaan hyvin lypsäviä lehmiä. Tiedostamalla hiehonkasvatuksen kustannukset, vältetään hiehoautomaatin syntymistä lypsykarjatilalla eli lehmiä ei poisteta turhaan. Näin saadaan karjan keskipoikimakerrat nousemaan ja lisää tuotantovuosia/lehmä.

eHieho kehitettiin hiehonkasvatuksen kustannusten laskentaan, joka on tuotteistettu laskurin muotoon. Laskuri - eHieho on tarkoitettu ja saatavilla neuvojien, yrittäjien ja muiden alan ammattilaisten käyttöön hiehon kasvatuksen ulkoistamisen suunnittelun tueksi. Laskurilla voidaan selvittää hiehon tuotantokustannus ja eläinkohtainen hoitopäiväkustannus (http://hiehohotelli.savonia.fi/eHieho).

eHieho - laskurin tavoitteena oli helppokäyttöinen laskuri, jolla voi laatia luotettavan tuotantokustannuslaskelman kohtuullisessa ajassa. eHieho on laadittu Microsoft Excel ohjelmalla ja sen tekemiseen on käytetty Visual Basic for Applications -ohjelmointia (VBA).

Hyvässä käyttöliittymässä on tanskalaisen käytettävyystutkijan, Jakob Nielsenin määritelmän mukaan viisi ominaisuutta: opittavuus, tehokkuus, virheettömyys, muistettavuus ja miellyttävyys. Testaajilta saadun palautteen perusteella tavoitteiden saavuttamisessa on onnistuttu hyvin.

Hyvien ohjeiden avulla saadaan aikaan mahdollisimman paikkaansa pitävä hiehojen tuotantokustannuslaskelma. eHieho -ohjeet ovat yksi tärkeä osa eHieho -laskurin kokonaisuutta. Laskuri on suunniteltu käyttöominaisuuksiltaan niiin, että sillä on mahdollista tehdä tuotantokustannuslaskelma ilman ohjeitakin. Laskurin käyttäjä, joka ei ole perehtynyt tuotantokustannuslaskentaan, pystyy ohjeiden ja laskentaesimerkkien avulla laatimaan luotettavan tuotantokustannuslaskelman. Edelleen eHieho -laskurin käyttäjä voi vertailla omia laskelmiaan mallilaskelmiin tai muiden tuottajien laskelmiin ja kehittää tilojen kannattavuutta. Kannattavuuden parantamiseen vaaditut ratkaisut lähtevät liikkeelle siitä, että ongelma omassa tuotannossa huomataan ja sen merkitys ymmärretään.

\section{Asiasanat}

Maidontuotanto, hiehot, uudistus, tuotantokustannus, ulkoistaminen 


\section{Johdanto}

Maitotuotteiden kysynnän kehitys maailmanmarkkinoilla tuo suomalaiselle maidonjalostusteollisuudelle ja maidontuottajille mahdollisuuksia, mutta samalla myös vakavia haasteita. Vakaan tuottajahinnan markkinoilta on siirrytty tilanteeseen, jossa hinta vaihtelee. Myös maatalouspolitiikan muutokset tuovat paineita suomalaisen maidontuotannon kilpailukyvyn kehittämiseen.

Tuotannon laajentaminen on keino reagoida hintavaihteluihin, mutta se edellyttää maitotilalla usein suuria investointeja tuotantorakennukseen ja eläimiin. Tilan tuotannon siirtäminen huomattavasti suurempaan kokoluokkaan edellyttää aina myös hyvin suunniteltua työnkäytön järjestämistä ja hyvää logistiikan suunnittelua. Useimmiten lypsykarjatilalla kasvatetaan myös uudistukseen tuleva karja-aines. Hiehoilla on kuitenkin erilainen hoito, rehuvaatimus ja ruokinta kuin lehmillä.

Noin puolet hiehon tuotantokustannuksesta on muuttuvia kustannuksia (rehut, kuivikkeet, lääkintä jne.) ja kolmannes työkustannusta. Loppuosa kustannuksesta jakautuu rakennus- ja konekustannusten sekä yleiskustannusten kesken.

Hiehohotelli -hankkeen suunnitteluvaiheessa oletettiin, että hiehonkas vatuksen siirtäminen maitotilan ulkopuolelle vapauttaa tilaa ja työpanosta lypsylehmien lisäämiselle ja parantaa näin maidontuotannon kannattavuutta. Hankkeessa haluttiin myös selvittää, kannattaako hiehonkasvatuksen ulkoistaminen uuden tuotantorakennuksen yhteydessä. Hiehonkasvatuksen ulkoistaminen avaa uusia mahdollisuuksia kotieläintuotantoon hiehonkasvatusyrittäjyyden muodossa. Hankkeessa haluttiin selvittää, millä edellytyksillä erikoistunut hiehonkasvatusyrittäjyys on mahdollista ja mitkä ovat sen kriittiset kohdat.

Uudistuskustannus eli hiehonkasvatuksen kustannukset ovat 10-15\% maidon tuotantokustannuksesta. Uudistuskustannus voi olla jopa puolet maidontuotannon muuttuvista kustannuksista. Hiehon kasvatusajalla on merkitystä eläimen elinikäistuotokseen eli siihen, kuinka paljon se tuottaa maitoa elämänsä aikana. Kiinnittämällä huomio hiehon ruokintaan ja hoitoon, saadaan hyvin lypsäviä lehmiä. Tiedostamalla hiehonkasvatuksen kustannukset, vältetään hiehoautomaatin syntymistä lypsykarjatilalla eli lehmiä ei poisteta turhaan. Näin saadaan karjan keskipoikimakerrat nousemaan ja lisää tuotantovuosia/lehmä.

eHieho kehitettiin hiehonkas vatuksen kustannusten laskentaan, joka on tuotteistettu laskurin muotoon. Laskuri - eHieho on tarkoitettu ja saatavilla neuvojien, yrittäjien ja muiden alan ammattilaisten käyttöön hiehon kasvatuksen ulkoistamisen suunnittelun tueksi. Laskurilla voidaan selvittää hiehon tuotantokustannus ja eläinkohtainen hoitopäiväkustannus (http://hiehohotelli.savonia.fi/eHieho).

\section{Aineisto ja menetelmät}

Hiehonkasvatuksen toimintamallien taloudellista mielekkyyttä tarkasteltiin sekä hiehonkasvatuksen ulkoistajan (lypsykarjatila), että hiehonkas vattajan näkökulmista katetuottomenetelmän mukaista taloussuunnitelmaa käyttäen. Laskentaa varten valittiin case-tarkasteluun todellisia maatiloja, joille laskettiin kannattavuus nykyiselle tuotantotavalle sekä vaihtoehtoiselle tuotannolle, joka liittyy hiehonkasvatuksen ulkoistamiseen.

Selvitystä varten laadittiin viisi tilaesimerkkiä: 1) keskikokoinen lypsykarjatila, joka ulkoistaa hiehonkasvatuksen, 2) keskikokoinen lypsykarjatila, joka vaihtaa tuotantosuuntaa ja rakentaa uuden hiehokasvattamon, 3) yhden lypsyrobotin lypsykarjatila, joka lisää lehmämäärää ulkoistamalla hiehonkasvatuksen, 4) uuden ison lypsykarjanavetan rakentaminen nuorkarjapaikoilla ja ilman sekä 5) uusi hiehokasvattamo, jossa vaihtoehtona on sonnivasikoiden välikasvattamona toimiminen hiehokasvattamon lisäksi (ns."mixed model").

Katetuottomenetelmän mukainen taloussuunnitelma mahdollistaa vaihtoehtojen välisen vertailun. Menetelmässä voidaan vakioida tekijöitä, kuten tuotantopanosten hinta. Kun muutetaan vain niitä tekijöitä, jotka todellisuudessakin vaihtoehtojen välillä eroavat, saadaan esiin kannattavuuserot vaihtoehtojen välillä. Varioimalla eri tekijöitä, kuten maidon hintaa, hiehon kasvatuspäivän hintaa, investointikustannusta tai työmäärää pitäen samalla muut tekijät vakiona, löydetään tekijät, jotka vaikuttavat voimakkaimmin kannattavuuden muutoksiin.

Tilatasolla päätöksiä tehtäessä tilakohtaiset rajoitteet on otettava huomioon. Siksi hankkeessa käytettiin laskelmissa case-tiloja, joille laskettiin kannattavuus nykyiselle tuotannolle sekä vaihtoehdolle. Näin mallintamalla pyrittiin kuvaamaan mahdollisimman todenmukaista yrittäjän päätöksentekotilannetta.

Tuloksista tarkasteltiin erityisesti yrittäjätuloa ja kannattavuuskerrointa. Yrittäjätulo on yrittäjän omalle työlle ja pääomalle saatava korvaus. Kannattavuuskerroin saadaan, kun yrittäjäperheen palkkavaatimuksen ja oman pääoman korkovaatimuksen summa jaetaan yrittäjätulolla. Se siis osoittaa, kuinka hyvin tavoitteeseen 
päästään. Esimerkkitapauksissa yrittäjäperheen palkkavaatimuksena käytettiin $14 \mathrm{e} / \mathrm{h}$ ja oman pääoman korkovaatimuksena $5 \%$ :a.

Hiehon kasvatusajalla on merkitystä eläimen elinikäistuotokseen eli siihen, kuinka paljon lehmä tuottaa maitoa elämänsä aikana. Hiehonkasvatusprosessissa huomio kiinnitetään ruokintaan ja hoitoon, näin saadaan hyvin lypsäviä lehmiä. Tiedostamalla hiehon aiheuttamat kustannukset, vältetään hiehoautomaatin syntymistä. Jokaisen poikivan hiehon elämä tulisi olla suunniteltu, jolloin lehmillä ei tule turhia poistoja. Näin saadaan keskipoikimakerrat nousemaan ja tuotantovuosia lisää. Tarvetta on saada apuväline laskentaan ja selvittää, mitä hiehon kasvattaminen maksaa lypsykarjatilalla tai hiehonkas vattajayrityksessä.

eHieho kehitettiin hiehonkas vatuksen kustannusten laskentaan, joka on tuotteistettu laskurin muotoon. Laskuri - eHieho on tarkoitettu ja saatavilla neuvojien, yrittäjien ja muiden alan ammattilaisten käyttöön hiehon kasvatuksen ulkoistamisen suunnittelun tueksi. Laskurilla voidaan selvittää hiehon tuotantokustannus ja eläinkohtainen hoitopäiväkustannus (http://hiehohotelli.savonia.fi/eHieho).

\section{Tulokset ja tulosten tarkastelu Ulkoistamisstrategiat}

Tila voi ulkoistaa hiehonkasvatuksen usealla eri tavalla. Eri tapoja erottavana tekijänä on eläinten siirtojen ja kerrallaan siirrettävien eläinten lukumäärä vuodessa TTS Työtehoseuran tekemien selvitysten mukaan näitä molempia tapoja on tiloilla käytössä.

Osa tiloista siirtää aina tietyn ikäiset eläimet kasvattamoon, esimerkiksi ternivasikkana tai 4 kk ikäisenä vasikkana. Samoin siirto takaisin lypsykarjanavettaan tapahtuu aina samassa vaiheessa poikimiseen nähden, yleensä $2 \mathrm{kk}$ ennen poikimista. Tilan koosta riippuen kerrallaan on siirrettävänä vain yksittäisiä eläimiä tai pieniä ryhmiä (Kuva 1, Malli 1).

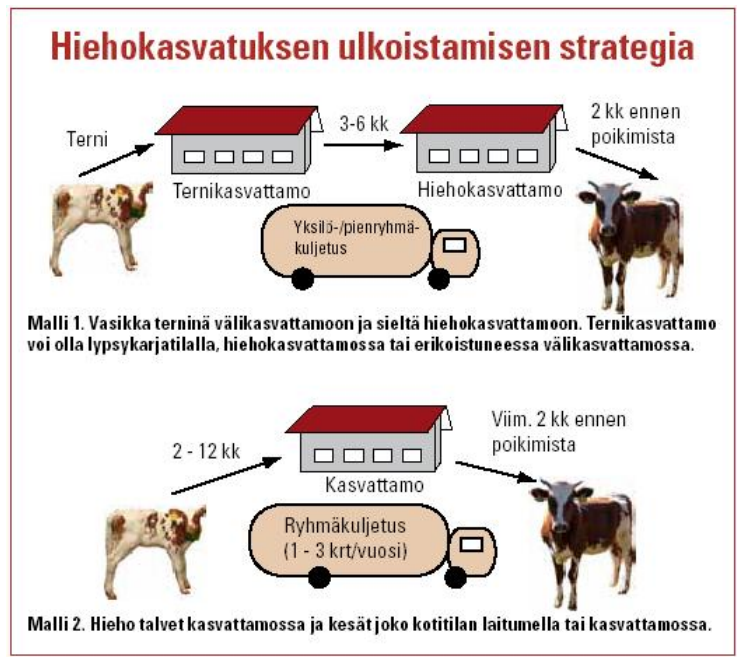

Kuva1. Hiehonkasvatuksen ulkoistamisen strategiat.

Osa tiloista siirtää eläimet aina tiettyyn aikaan vuodesta, esimerkiksi laidunkauden päättyessä lypsykarjatilalta kasvattamoon ja takaisin taas laidunkauden alkaessa. Näin menetellään siinä tilanteessa, jos lypsykarjatila haluaa hyödyntää laitumet tehokkaasti ja tilalla on esim. perinnebiotooppeja, joita nuorkarja laiduntaa. Tässä tapauksessa siirrettävänä on kerrallaan isompi eläinryhmä (Kuva 1, Malli 2).

\section{Ulkoistamisen kannattavuus keskikokoisella lypsykarjatilalla}

Tarkasteltavana olleella keskikokoisella lypsykarjatilalla oli lähtötilanteessa 22 lypsylehmää. Navetassa oli kuitenkin lypsylehmien käyttöön otettavia parsipaikkoja, joten maidontuotantoa pystyttäisiin tehostamaan olemassa olevan rakennuksen sisällä. Tilalle laskettiin kaksi erilaista mallia ulkoistamisen: 1) nuorkarjan siirto lypsykarjatilan ja kasvattamon välillä kaksi kertaa vuodessa, eli isompina eläinryhminä (Kuva 1, Malli 2) ja 2) nuorkarjan siirto lähettäjän ja kasvattajan välillä yksilöinä tai pienryhminä niin, että vasikat siirretään kasvattamoon n. 4-5 kk iässä ja takaisin lypsykarjatilalle n. 2 kk ennen poikimista (Kuva 1, Malli 1). Navettaan hankittiin lisää lypsy-yksiköitä, jotta työmäärä ei kasvaisi kohtuuttomasti lehmämäärän lisääntyessä. Mallin 2 mukaan ulkoistettaessa nuorkarja lähtee kasvattamoon aina laidunkauden lopussa lokakuussa ja palaa takaisin lypsykarjatilalle toukokuussa laitumelle. Kasvattamossa eläimet siis ovat kerrallaan n. 7 kk ajan. Näin lehmämäärä saadaan nostettua 30:een. Koko navetan kapasiteettia ei saada hyödynnettyä, sillä tilaa tarvitaan sisäruokintakauden aikana poikiville hiehoille ja myös sisäruokintakauden aikaan syntyville vasikoille.

Kun tila ulkoistaa kasvatuksen mallin 1 mukaan, jolloin vasikat siirretään kasvattamoon n. kerran kuukaudessa ja tiineet hiehot palaavat takaisin noin kaksi kuukautta ennen poikimista, tila saa nostettua lehmämäärän 35:een. Tässä tapauksessa navetan maidontuotantokapasiteetti hyödynnetään hyvin tehokkaasti. Ongelmaksi saattaa kuitenkin muodostua työmäärä, jolloin erilaisia teknologiaratkaisuja kannattaa miettiä.

Keskikokoiselle lypsykarjatilalle hiehonkasvatuksen ulkoistaminen on kannattavaa (Taulukko 1.). Kun 
olemassa oleva tuotantorakennus saadaan mahdollisimman tehokkaasti maidontuotantokäyttöön, sekä yrittäjätulo että kannattavuuskerroin paranevat.

Taulukko 1. Hiehonkasvatuksen ulkoistamisen taloudellisia vaikutuksia keskikokoiselle lypsykarjatilalle. Vertailua kahden eri ulkoistamisstrategian välillä.

\begin{tabular}{|c|c|c|c|c|c|}
\hline & $\begin{array}{l}\text { Ennen ulkois- } \\
\text { tamista }\end{array}$ & $\begin{array}{l}\text { Hiehonkasv. ul- } \\
\text { koistettu, siirto } \\
\text { kerran vuodessa } \\
\text { kasvattamoon } \\
\text { ryhmänä }\end{array}$ & $\begin{array}{l}\text { Erotus lähtö- } \\
\text { tilanteeseen }\end{array}$ & $\begin{array}{l}\text { Hiehonkasv. ulkois- } \\
\text { tettu, siirto kerran } \\
\text { kuukaudessa kasvat- } \\
\text { tamoon }\end{array}$ & $\begin{array}{l}\text { Erotus lähtö- } \\
\text { tilanteeseen }\end{array}$ \\
\hline Lypsylehmiä & 22 & 30 & +8 & 35 & +13 \\
\hline Tuotettu maitoa $(\mathrm{kg})$ & 200200 & 273000 & +72800 & 318500 & +118300 \\
\hline Poikivia hiehoja / vuosi & 9 & 12 & +3 & 14 & +5 \\
\hline $\begin{array}{l}\text { Kasvatuspäiviä yhteen- } \\
\text { sä, vrk (tilan ulkopuolel- } \\
\text { la) }\end{array}$ & & 2743 & & 5880 & \\
\hline $\begin{array}{l}\text { Ulkoistuskustannus } \\
\text { e/vuosi (*(alv 0\%) }\end{array}$ & & 7250 & & 16000 & \\
\hline Säilörehualan tarve, ha & 16 & 18 & +2 & 22 & +6 \\
\hline Laidunalan tarve, ha & 6,5 & 9 & $+2,5$ & 6,5 & 0 \\
\hline Lantamäärä, $\mathrm{m}^{3}$ & 660 & 750 & +90 & 900 & +240 \\
\hline Yrittäjätulo, $€$ & 27333 & 38142 & +10809 & 45159 & +17826 \\
\hline Kannattavuuskerroin & 0,33 & 0,45 & $+0,12$ & 0,50 & $+0,17$ \\
\hline Työtuntimäärä, h/vuosi & 3929 & 4072 & +143 & 4413 & +484 \\
\hline $\begin{array}{l}\text { Maidon hinta, } € / 1 \text { (ilman } \\
\text { tukialue } C 2: \text { n pohjoista } \\
\text { tukea) } \\
\text { (alv } 0 \%)\end{array}$ & 0,3779 & 0,3779 & & 0,3779 & \\
\hline $\begin{array}{l}\text { Kasvatuspäivän hinta, } € \\
\text { (alv } 0 \%)\end{array}$ & & 2,50 & & 2,50 & \\
\hline $\begin{array}{l}\text { Nettoinvestoinnit, } €(* * \\
(\operatorname{alv} 0 \%)\end{array}$ & & 6900 & & 15000 & \\
\hline
\end{tabular}

*) sisältää kasvatuskustannuksen, kuljetukset ja salmonellatestauksen

**) sisältää navetan muutoskustannuksen, lisälypsy-yksiköiden hankinnan ja lypsykoneen päivityksen.

\section{Ulkoistamisen kannattavuus yhden robotin navetassa}

Toisena hiehonkasvatuksen ulkoistamisen tapauksena tarkasteltiin 70 lehmän pihattonavettaa, joka ulkoistaa hiehonkasvatuksen ja ottaa käyttöön toisen lypsyrobotin. Tilalla on 2000-luvun alussa rakennettu pihatto, joka on malliltaan keskikäytävänsä suhteen epäsymmetrinen. Vasikat lähtevät kasvattamoon n. kahden viikon iässä ja palaavat takaisin lypsykarjatilalle $2 \mathrm{kk}$ ennen poikimista. Lehmämäärä saadaan nostettua 125:een, eli kahden robotin kapasiteettia ei täysin saada hyödynnettyä. Työmäärää kohtuullistaakseen tila päättää ulkoistaa pääosan peltotöistä.

Taulukko 2. Hiehonkasvatuksen ulkoistamisen taloudellisia vaikutuksia yhden robotin tilalla.

\begin{tabular}{|l|c|c|c|}
\hline & $\begin{array}{c}\text { Hiehonkasvatus lyp- } \\
\text { sykarjatilalla, yksi lyp- } \\
\text { syrobotti }\end{array}$ & $\begin{array}{c}\text { Hiehonkasvatus ulkoistettu } \\
\text { ja kaksi lypsyrobottia }\end{array}$ & Erotus \\
\hline Lypsylehmiä & 70 & 125 & +55 \\
\hline Tuotettu maitoa (kg) & 623000 & 1112500 & +489500 \\
\hline Poikivia hiehoja / vuosi & 28 & 50 & +22 \\
\hline $\begin{array}{l}\text { Kasvatuspäiviä yhteensä } \\
\text { (tilan ulkopuolella), vrk }\end{array}$ & & 83000 & \\
\hline $\begin{array}{l}\text { Ulkoistuskustannus e/vuosi } \\
(* \text { (alv 0\%) }\end{array}$ & & 32300 & \\
\hline
\end{tabular}




\begin{tabular}{|l|c|c|c|}
\hline Säilörehualan tarve, ha & 85 & 122 & +37 \\
\hline Lantamäärä, $\mathrm{m}^{3}$ & 2700 & 3300 & +600 \\
\hline Yrittäjätulo, $€$ & 125385 & 137370 & +11985 \\
\hline Kannattavuuskerroin & 1,27 & 1,38 & +610 \\
\hline Työtuntimäärä, h/vuosi & 4264 & 0,3779 & \\
\hline $\begin{array}{l}\text { Maidon hinta (ilman tukialue } \\
\text { C2:n pohjoista tukea), } € / 1 \\
(\text { alv 0 \%) }\end{array}$ & 0,3779 & & \\
\hline $\begin{array}{l}\text { Kasvatuspäivän hinta, } €,(\text { alv } \\
0 \%)\end{array}$ & & 2,50 & \\
\hline $\begin{array}{l}\text { Lisäkiintiön hankinta, 0,04 e } \\
\text { / litra (alv 0\%) }\end{array}$ & & 19580 & \\
\hline $\begin{array}{l}\text { Nettoinvestoinnit, } €(* * \\
\text { (alv 0\%) }\end{array}$ & & 144840 & \\
\hline
\end{tabular}

*) sis. kasvatuskustannuksen, kuljetukset ja salmonellatestauksen, **) sis. navetan muutoskustannuksen, lietelantalan, toisen lypsyrobotin hankinnan, maitokiintiön oston sekä tarpeettomaksi käyneiden peltotyökoneiden myynnin.

Tässä tapauksessa kannattavuuden paraneminen on varsin vähäistä ja sen voi katsoa jäävän normaalin vuotuisen vaihtelun sisään (Taulukko 2). Erityisesti kannattavuuden paranemista heikentää lypsyrobottien kapasiteetin jääminen vajaaksi. Epäsymmetrisen pohjaratkaisun pihatoissa ei siis saada välttämättä navetan käyttöä tehostettua ilman merkittäviä investointeja.

\section{Ulkoistamisen kannattavuus uutta navettaa rakennettaessa}

Kolmas ulkoistajatapaus oli uuden pihattonavetan rakentaminen. Tässä tarkasteltiin sitä, kannattaako uuteen navettaan rakentaa tilat nuorkarjalle, vai ulkoistaa nuorkarjan kasvatus. Tilalla rakennetaan uusi, n. 160 lehmän pihattonavetta. Laskelmissa on huomioitu mahdollinen vajaatäyttö, joten eläinmääräksi on arvioitu keskimäärin 153 lehmää. Vaihtoehtoina on joko rakentaa navetan yhteyteen paikat nuorkarjalle, tai ulkoistaa hiehonkasvatus ja rakentaa navetta pelkästään lypsylehmille. Nurmialan tarve on ensimmäisessä vaihtoehdossa 24 hehtaaria suurempi, kuin ulkoistamisvaihtoehdossa (Taulukko 3).

Taulukko 3. Hiehonkasvatuksen ulkoistamisen taloudellisia vaikutuksia uuden lypsykarjapihaton rakentavalla tilalla.

\begin{tabular}{|c|c|c|c|}
\hline & $\begin{array}{l}\text { Hiehonkasvatus lyp- } \\
\text { sykarjatilalla }\end{array}$ & $\begin{array}{c}\text { Hiehonkasvatus } \\
\text { ulkoistettu }\end{array}$ & Erotus \\
\hline Lypsylehmiä & 153 & 153 & \\
\hline Tuotettu maitoa, kg & 1361700 & 1361700 & \\
\hline Poikivia hiehoja / vuosi & 61,2 & 61,2 & \\
\hline $\begin{array}{l}\text { Kasvatuspäiviä yhteensä, } \\
\text { vrk (tilan ulkopuolella) }\end{array}$ & & 39535 & \\
\hline $\begin{array}{l}\text { Ulkoistuskustannus } € / \text { vuosi } \\
\text { (*(alv } 0 \%)\end{array}$ & & 101400 & \\
\hline Säilörehualan tarve, ha & 150 & 126 & -24 \\
\hline Lantamäärä, $\mathrm{m}^{3}$ & 4406 & 3680 & -600 \\
\hline Yrittäjätulo, € & 259538 & 247107 & -12431 \\
\hline Kannattavuuskerroin & 2,05 & 1,83 & $-0,22$ \\
\hline Työtuntimäärä, h/vuosi & 6187 & 5314 & -873 \\
\hline $\begin{array}{l}\text { Palkatun työvoiman tarve, } \\
\text { h/vuosi }\end{array}$ & 2000 & 1127 & -873 \\
\hline $\begin{array}{l}\text { Maidon hinta, } € / 1 \text { (ilman } \\
\text { tukialue } C 2: \text { p pohjoista tu- } \\
\text { kea) (alv } 0 \% \text { ) }\end{array}$ & 0,3779 & 0,3779 & \\
\hline $\begin{array}{l}\text { Kasvatuspäivän hinta, } € \text { (alv } \\
0 \% \text { ) }\end{array}$ & & 2,50 & \\
\hline $\begin{array}{l}\text { Nettoinvestoinnit }(* * \\
(\text { alv } 0 \%)\end{array}$ & 1,734 M€ & 1,45 M€ & $-284000 €$ \\
\hline
\end{tabular}

*) sis. kuljetukset ja salmonellatestauksen **) erotus sis. nuorkarjan osaston navettaan ja lietelantalan laajennuksen 
Tässä tapauksessa hiehonkasvatus pystytään järjestämään tilalle rakennettavassa nuorkarjaosastossa niin tehokkaasti, ettei ulkoistaminen ole taloudellisesti kannattavaa, jos kasvatuspäivän hinta on 2,50 €/vrk (taulukko 3). Jos taas kasvatuspäivän hinta on $2 € /$ vrk, kannattavuusero vaihtoehtojen välillä on hyvin pieni, joten molemmat vaihtoehdot ovat varteenotettavia.

Laajentavalla tilalla on tekijöitä, jotka rajoittavat suunniteltua eläinmäärää. Esimerkiksi peltoalan saatavuus saattaa olla este eläinmäärän lisäämiselle ja tässä tapauksessa nuorkarjan kasvattamiselle omalla tilalla. Tällöin tilalla investoinnin yhteydessä punnitaankin sitä, rakennetaanko yhden robotin tila ja kasvatetaan nuorkarja itse vai kahden robotin tila ja ulkoistetaan nuorkarjan kasvatus.

\section{Erikoistuneen hiehokasvattamon kannattavuuden edellytykset}

Hiehokasvattamon kannattavuuden edellytysten tarkastelua varten tehtiin vertailulaskelmaa siitä, kannattaako keskikokoisen lypsykarjatilan luopua maidontuotannosta ja perustaa hiehokasvattamo. Toinen kasvattamotarkastelu tehtiin siitä, kannattaako ison, erikoistuneen kasvattamon kasvattaa vain hiehoja vai toimia myös ns. välikasvattamona sopimustilojen sonnivasikoille. Tavoitteena oli löytää erikoistuneen hiehonkasvatuksen kriittiset kohdat ja onnistumisen edellytykset.

Taulukko 4. Tuotantosuunnan vaihdoksen taloudellisia vaikutuksia, kun keskikokoinen lypsykarjatila luopuu maidontuotannosta ja perustaa hiehokasvattamon.

\begin{tabular}{|c|c|c|c|}
\hline & Lypsykarja & $\begin{array}{c}\text { Erikoistunut hiehon- } \\
\text { kasvatus }\end{array}$ & Erotus \\
\hline Lypsylehmiä & 22 & & \\
\hline Tuotettu maitoa $(\mathrm{kg})$ & 200200 & & \\
\hline Hiehopaikkoja & 9 & 180 & \\
\hline $\begin{array}{l}\text { Myytyjä kasvatuspäiviä yh- } \\
\text { teensä, vrk/vuosi (täyttöaste } \\
95 \% \text { ) }\end{array}$ & & 61560 & \\
\hline Säilörehualan tarve, ha & 15 & 41 & +26 \\
\hline Lantamäärä, $\mathrm{m}^{3}$ & 663 & $\begin{array}{c}2179 \text { (liete) } \\
+100 \text { kuivikelanta }\end{array}$ & $\begin{array}{c}+1516 \text { (liete) } \\
+100 \text { (kuivikelanta) }\end{array}$ \\
\hline Yrittäjätulo, $€$ & 28138 & 30746 & +2608 \\
\hline Kannattavuuskerroin & 0,34 & 0,57 & $+0,23$ \\
\hline Työtuntimäärä, h/vuosi & 3929 & 2596 & -1333 \\
\hline $\begin{array}{l}\text { Kasvatuspäivän hinta, } € \\
(\text { alv } 0 \%)\end{array}$ & & 2,50 & \\
\hline $\begin{array}{l}\text { Nettoinvestoinnit, } € \text { (* } \\
\text { (alv } 0 \% \text { ) }\end{array}$ & & 422000 & \\
\hline
\end{tabular}

*) sisältää rakennuksen ja koneet, investointiavustus otettu huomioon

Tässä esimerkissä tilan kannattavuus paranee, kun tila vaihtaa tuotantosuuntaa maidontuotannosta erikoistuneeseen hiehonkasvatukseen (Taulukko 4). Yrittäjätulon kasvu jää vähäiseksi, mutta työmäärä pienenee. Hiehonkasvatuksessa on maidontuotantoon verrattuna erilaisia osaamisvaatimuksia, kuten palveluiden markkinointi ja yhteydenpito asiakkaisiin. Selvityksen mukaan erikoistuneen hiehokasvattamon kannattavuuteen vaikuttaa tuotantokustannusten lisäksi merkittävimmin kasvatuspäivän hinta ja täyttöasteen muutos.

"Mixed model" - versiossa ongelmaksi saattaa muodostua kasvattamon koko. Ainakin suurilla teurastamoilla vakiintunut välikasvatetun sonniryhmän koko on 30 eläintä, jotka ovat mahdollisimman saman ikäisiä. Tässä tapauksessa päästäisiin vain kolmasosaan siitä. On siis epävarmaa, löytyisikö yhteistyökumppania, joka ostaisi puolivuotiaat sonnit välikasvatettujen hinnalla. Siksi laskelma tehtiin myös vaihtoehdolle, jossa sonnit myydään normaaleina välitysvasikoina 4 kk iässä.

Taulukko 5. Hiehokasvattamon ja "mixed model" -toimintamallin vertailua.

\begin{tabular}{|l|c|c|c|}
\hline & Hiehokasvattamo & $\begin{array}{c}\text { Mixed model } \\
\text { (4 kk ikään) }\end{array}$ & $\begin{array}{c}\text { Mixed model } \\
\text { (6 kk ikään) }\end{array}$ \\
\hline Myytyjä hiehoja /vuosi & 151 & 129 & 129 \\
\hline Myytyjä sonnivasikoita / vuosi & & 129 & 129 \\
\hline "Myytyjä" kasvatuspäiviä yht- & 97158 & 97158 & 97158
\end{tabular}




\begin{tabular}{|l|c|c|c|}
\hline eensä & & & \\
\hline Säilörehualan tarve, ha & 56 & 50 & 54 \\
\hline Yrittäjätulo, $€$ & 106251 & 87889 & 104560 \\
\hline Kannattavuuskerroin & 1,16 & 0,93 & 1,09 \\
\hline Työtuntimäärä, h/vuosi & 3778 & 4023 & 4023 \\
\hline
\end{tabular}

Esimerkkitapauksessa pelkkien hiehojen kasvattaminen olisi kannattavampaa, kuin malli, jossa toimitaan välikasvattamona sonnivasikoille (taulukko 5). Ero johtuu lähinnä siitä, että sonnivasikan markkinahinta on lehmävasikkaa korkeampi ja lisäksi sonnit ovat tilalla kaikkein kalleimman kasvatusajan, jolloin vasikka syö suhteessa enemmän kallista rehua (juottorehu, väkirehu). Jos tila löytää yhteistyökumppanin, joka on valmis ostamaan puolivuotiaat sonnit välikasvatetun naudan hinnalla, sekakasvattamovaihtoehto voi olla houkutteleva. Tällä toimintamallilla suurin etu olisi vajaatäytön riskin pienentäminen, kun kasvattamoon otettaisiin kaikki yhteistyötiloilla syntyvät vasikat.

\section{Hiehoautomaatti tulee kalliiksi}

Perinteisesti hiehoja kasvatetaan maidontuotantotilalla syntyneistä vasikoista tilan omiin uudistustarpeisiin. Usein hiehonkasvatus on tehotonta ja tuotantopotentiaalia haaskataan karsimalla turhaan lehmiä,jotta poikiva hieho saadaan lypsypaikalle. Pahimmillaan kaikki lehmävasikat jätetään kasvamaan uudistukseen miettimättä, edistääkö se karjan jalostusta. Tuottamattomia eläinpaikkoja tarvitaan näin ollen enemmän. Syynä hiehoautomaatin muodostumiseen on usein, ettei tiedosteta kustannuksia, joita hiehon kasvatus aiheuttaa. (Hiehonkasvatuksen ulkoistaminen 2011, 8 - 23.) Hiehon kasvatus voi epäonnistua jo vasikkavaiheessa. Tämä johtaa siihen, että hiehot saattavat poikia huomattavan vanhoina, jopa yli 30 kuukauden iässä. Laajentavilla tiloilla voi hiehojen kiimaseuranta ja kasvavien eläinten kehityksen seuranta olla huonoa ajanpuutteen vuoksi.

\section{eHieho hiehonkasvatuksen kustannusten laskentaan}

Laskuri auttaa hahmottamaan selkeästi, mistä eri kustannuksista hiehon kasvatus koostuu, mitkä ovat merkittävimmät kustannuserät sekä kuinka eri asiat kytkeytyvät toisiinsa (kuva 2). Tavoitteena oli herättää hiehonkasvattajia huomaamaan, mistä eri kustannuksista kasvatuskulut koostuvat ja kuinka eri asiat kytkeytyvät toisiinsa. Laskurin avulla voi auttaa yrittäjää huomaamaan yhteys maidontuotannon kannattavuuteen.

eHieho - laskurin tavoitteena oli helppokäyttöinen väline, jolla voi laatia luotettavan tuotantokustannuslaskelman kohtuullisessa ajassa (kuvat 3 ja 4). eHieho on laadittu Microsoft Excel ohjelmalla ja sen tekemiseen on käytetty Visual Basic for Applications -ohjelmointia (VBA). Hyvässä käyttöliittymässä on tanskalaisen käytettävyystutkijan, Jakob Nielsenin määritelmän mukaan viisi ominaisuutta: opittavuus, tehokkuus, virheettömyys, muistettavuus ja miellyttävyys. Testaajilta saadun palautteen perusteella tavoitteiden saavuttamisessa on onnistuttu hyvin. 


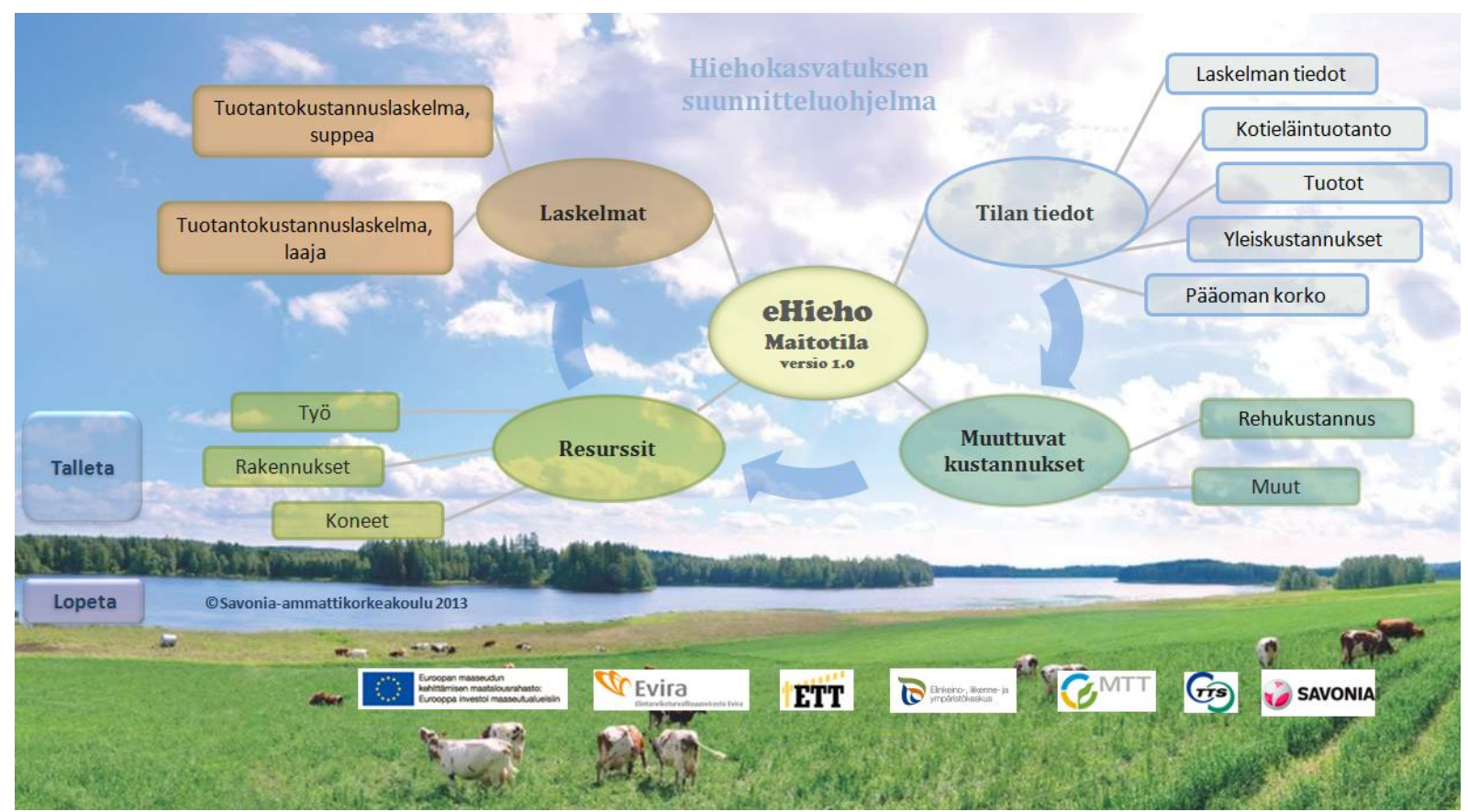

Kuva 3. eHieho - laskurin pääsivu.

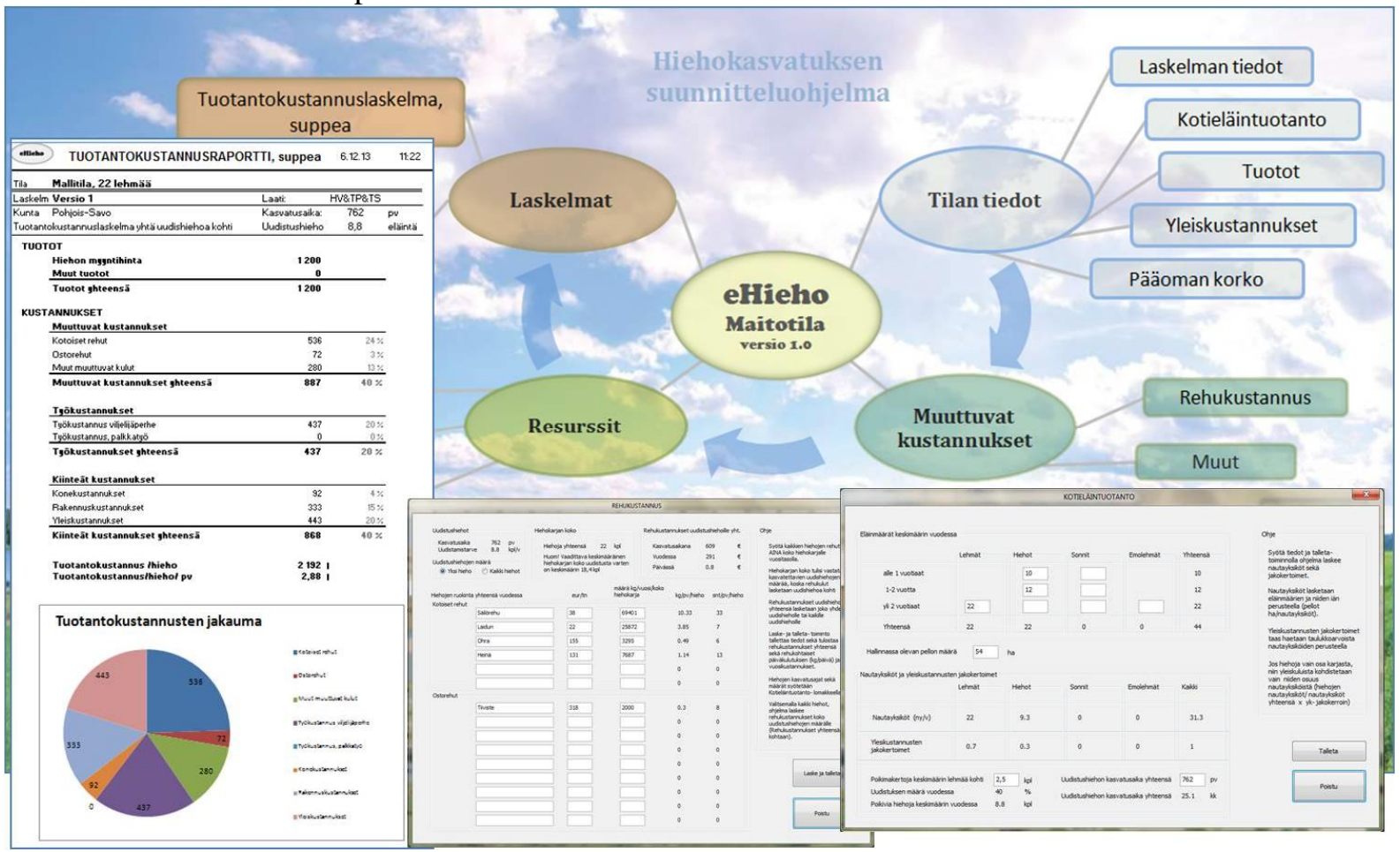

Kuva 4. eHieho - laskurin valikkonäkymä.

Selkeiden ohjeiden avulla saadaan aikaan mahdollisimman paikkaansa pitävä hiehojen tuotantokustannuslaskelma. eHieho -ohjeet ovat yksi tärkeä osa eHieho -laskurin kokonaisuutta. Laskuri on suunniteltu käyttöominaisuuksiltaan niin, että sillä on mahdollista tehdä tuotantokustannuslaskelma ilman ohjeitakin. Laskurin käyttäjä, joka ei ole perehtynyt tuotantokustannuslaskentaan, pystyy ohjeiden ja laskentaesimerkkien avulla laatimaan luotettavan tuotantokustannuslaskelman (kuva 5). Edelleen eHieho -laskurin käyttäjä voi vertailla omia laskelmiaan mallilaskelmiin tai muiden tuottajien laskelmiin ja kehittää tilojen kannattavuutta. Kannattavuuden parantamiseen vaaditut ratkaisut lähtevät liikkeelle siitä, että ongelma omassa tuotannossa huomataan ja sen merkitys ymmärretään. 


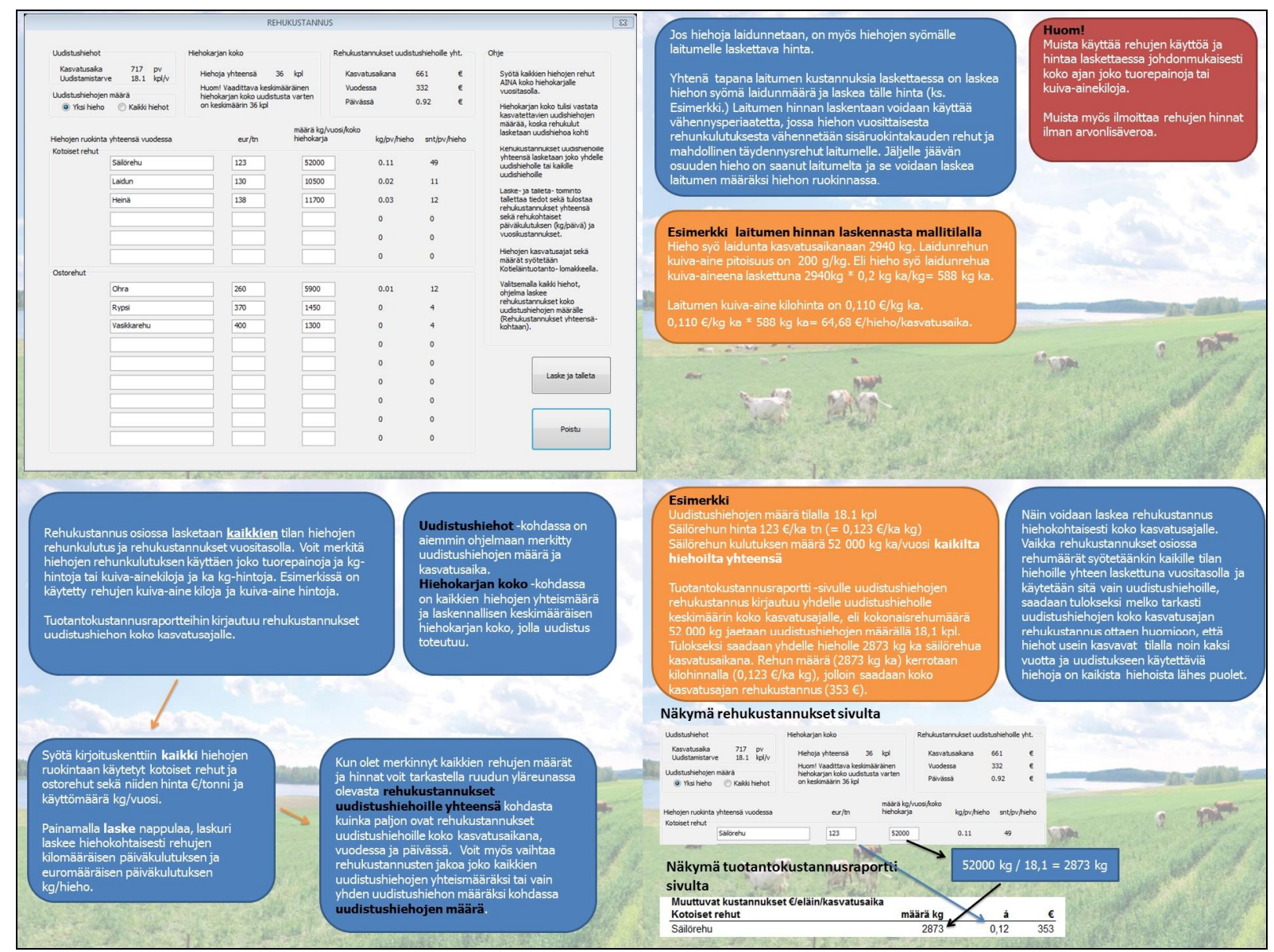

Kuva 5. eHieho - laskurin ohjeet.

\section{Johtopäätökset}

Hiehonkasvatuksen ulkoistamisella on hyvin järjestettynä mahdollisuus saavuttaa maidontuotannon tarvitsemaa erikoistumista ja lisätä kustannustehokuutta. Ulkoistaminen on case-esimerkkien perusteella kannattavaa, mikäli lypsykarjatila pystyy lisäämään tuotetun maidon määrää.

Mikäli maidon tuottajahinta laskee voimakkaasti, ulkoistamisen kannattavuus heikkenee. Myös kasvatuspäivän hinta vaikuttaa ulkoistamisen kannattavuuteen. Ulkoistaminen on sitä kannattavampaa, mitä suurempi keskituotos lypsykarjassa on.

Kasvatuspäivän hinnan määrittelyssä on otettava lähtökohdaksi hiehon tuotantokustannukset. Hinnan on oltava molempien osapuolten hyväksymä. Toisaalta hiehon kasvatuskustannukset tulevat tässä mallissa näkyväksi, jolloin uudistukseen kiinnitetään enemmän huomiota. Esimerkkilaskelmissa ei otettu huomioon sitä, että todennäköisesti lypsykarjatila harkitsee entistä tarkemmin uudistukseen tarvittavien eläinten määrää, kun niiden kasvatuksesta maksetaan ulkopuolisille. Näin saadaan hyvä kannuste esim. sukupuolilajitellun sperman käytölle, kun uudistusainesta halutaan vain parhaista lehmistä. Tämä taas saisi aikaan ns. hiehoautomaatin poistumisen. Monella tilalla joudutaan poistamaan hyvässä tuotosvaiheessa olevia lypsylehmiä,jotta uudistushiehoille saadaan riittävästi tilaa. Ennen pitkää tämä johtaisi karjan keskimääräisten poikimakertojen määrän kasvuun ja edelleen kannattavuuden paranemiseen, kun eläinpääomaa hyödynnetään entistä tehokkaammin. Toimintamallin päätavoite on saada entistä parempia ensikoita maitotilan tarpeisiin entistä tehokkaammalla resurssien käytöllä.

eHieho -laskuri on laadittu auttamaan yrittäjää laskemaan hiehonkasvatuksen kustannukset. Laskurin avulla, ohjeita ja mallilaskelmapohjia hyödyntäen hiehonkas vattaja kiinnittää huomiota oleellisiin asioihin ja näin kehittämään maidontuotantoa.

Laskelmat on tehty vakiintuneisiin tilanteisiin, eli tuotantosuunnan tai -määrän muutosvaiheen taloustarkastelua ei selvitykseen sisältynyt. Jatkossa olisikin syytä tarkastella, miten tilan maksuvalmiudelle tapahtuu, erityisesti siinä tilanteessa, kun tuotantosuunta vaihtuu maidontuotannosta hiehonkasvatukseen. 


\section{Kirjallisuus}

Ehnroth, A., Österman, P. \& Hannele, T. (toim) 2003. Laajentavien tilojen haasteet. ProAgria Maaseutukeskusten Liiton julkaisuja 998. Tieto tuottamaan 104.

Karhula, T., Ylätalo, M., Ryhänen, M. \& Latukka, A. 2002. Maitotilojen taloudellinen tulos ja kannattavuus 2000 - 2010. Helsingin yliopisto. Taloustieteen laitos. Julkaisuja 37: 155-213.

MTT. 2011. Taloustohtori. Saatavilla: http://www.mtt.fi/taloustohtori

Pellinen, J., Ehnroth, A. \& Harmoinen, T.(toim) 2008. Kannattava maatilayritys. ProAgria Maaseutukeskusten Liiton julkaisuja 1060. Tieto tuottamaan 124.

ProAgria 2009. Mallilaskelmia maataloudesta 2009. 48 s.

Ryhänen, M. \& Sipiläinen, T. \& Latukka, A. 2002. Maatalousyrityksen tuotannon suunnittelu ja kehittäminen. Helsingin yliopisto. Taloustieteen laitos. Opetusmoniste. Luonnos 3/2003. 169 s.

Ylätalo, M. \& Mäkinen, H. 1997. Maatilatalouden investoinnit, rahoitus ja maksuvalmius. Helsingin yliopisto. Taloustieteen laitoksen monistesarja 12:1-121. 